\title{
MANAJEMEN PENDISTRIBUSIAN ZAKAT DI BADAN AMIL ZAKAT NASIONAL (BAZNAS) PROVINSI KALIMANTAN SELATAN
}

\author{
Siti Rahmah \\ Relawan Badan Amil Zakat Nasional, Banjarmasin, Indonesia \\ Email: rahmah.alafifah@gmail.com \\ Jumi Herlita \\ Fakultas Dakwah dan Ilmu Komunikasi, UIN Antasari, Banjarmasin, Indonesia \\ Email: j3herlita@gmail.com
}

\begin{abstract}
The management of zakat distribution is very important to ensure that the zakat funds obtained by amil are channeled to the maximum and on target in accordance with sharia principles. This study attempts to analyze the management of zakat distribution in BAZNAS, South Kalimantan Province, covering activities of planning, organizing, implementing / mobilizing, and monitoring the distribution of zakat. This type of research is field research with a qualitative descriptive approach. The results of the study show that BAZNAS of South Kalimantan Province has carried out the distribution management function in accordance with management theory and there are several supporting factors and constraints on the distribution of zakat.
\end{abstract}

KEYWORDS Management; Distribution; Zakat

\section{Pendahuluan}

Zakat adalah salah satu sektor penting dalam filantropi Islam. Sebagai rukun Islam ketiga, zakat wajib dibayarkan oleh setiap Muslim yang memenuhi syarat (muzakki) untuk menyucikan hartanya dengan cara menyalurkan zakatnya kepada mustahik (penerima zakat). Zakat ini tidak hanya berfungsi untuk menolong perekonomian mustahik, tetapi juga dapat menjadi instrumen penyeimbang dalam sektor ekonomi nasional. Dalam jangka panjang, tujuan utama zakat adalah mentransformasi para mustahik menjadi muzakki apalagi Indonesia dengan mayoritas penduduk Muslim berjumlah 216,66 juta atau dengan persentase Muslim sebesar 85 persen dari total populasi (BPS, 2015) menyiratkan bahwa zakat memiliki potensi besar dan dapat berkontribusi dalam mengurangi kemiskinan di suatu negara.(PUSKAS BAZNAS, 2016)

Pengelolaan zakat tidak cukup hanya dengan niat yang baik saja, namun juga harus didasarkan pada tata kelola (governance) yang baik. Peran amil dan juga 
manajemen pengelolaan zakat yang professional diharapkan mampu memanfaatkan potensi zakat yang belum maksimal di tanah air.

Amil zakat yang ditunjuk oleh pemerintah untuk melaksanakan pengelolaan dana zakat secara nasional bernama Badan Amil Zakat Nasional (BAZNAS), mulai dari yang berkedudukan di Ibukota/Kota, berkedudukan di Provinsi, dan yang berkedudukan di Kabupaten/Kota. Lembaga ini berkewajiban fokus pada kegiatan perencanaan, pengorganisasian, pelaksanaan dan pengawasan terhadap pengumpulan dan penditribusian serta pendayagunaan zakat.(Kemenag RI jendral Bimbingan Masyarakat Islam Direktorat Pemberdayaan Zakat, 2012)

BAZNAS Provinsi Kalimantan selatan sebagai bagian yang terintegrasi dengan BAZNAS Pusat dibentuk berdasarkan Surat Keputusan Gubernur Kalimantan Selatan No. 188.44/0282/KUM/2015 yang berfungsi sebagai badan pengelola zakat, infaq, dan sedekah serta dana-dana sosial lainnya di Kalimantan Selatan.

Menurut Undang-Undang RI No 23 tahun 2011 tentang pengelolaan zakat menjelaskan bahwa Pengelolaan zakat adalah kegiatan perencanaan, pelaksanaan, dan pengoordinasian dalam pengumpulan, pendistribusian, dan pendayagunaan zakat. Supaya manfaat zakat dapat dirasakan oleh para mustahik tentunya peran pendistribusian menjadi hal yang perlu diperhatikan oleh para amil khususnya BAZNAS Provinsi Kalimantan Selatan. Selama ini penulis melihat bahwa masih banyak masyarakat yang belum mengetahui dan memanfaatkan BAZNAS Provinsi Kalimantan Selatan sebagai wadah untuk mengelola dan mendistribusikan zakat mereka yang sedikit banyak akan berpengaruh terhadap pengumpulan dan pendistribusian zakat di daerah Kalimantan selatan. Selain itu juga berbagai persoalan internal seperti sumber daya manusia yang terbatas menyebabkan ruang gerak lembaga menjadi terbatas.

Berdasarkan hal tersebut, penulis tertarik untuk meneliti bagaimana manajemen pendistribusian zakat yang dilakukan oleh BAZNAS Provinsi Kalimantan Selatan.

\section{Kajian Teori}

A. Tinjauan tentang Manajemen

Manajemen merupakan suatu proses yang khas terdiri dari tindakan perencanaan, pengorganisasian, penggerakan dan pengendalian yang dilakukan untuk menentukan serta mencapai sasaran-sasaran yang telah ditentukan melalui pemanfaatan sumber daya manusia dan sumber-sumber lainnya.(Malayu S.P Hasibuan, 1995) Manajemen merupakan prasyarat bagi organisasi atau perundang-undangan zakat untuk mencapai sebuah tujuan sebagaimana yang telah dilakukan oleh orang-orang ikhlas yang berdiri di bawah panji-panji syari"ah.( Muhammad Hadi, 2010) 
B. Tinjauan tentang Pendistribusian

Pendistribusian merupakan penyaluran atau pembagian sesuatu kepada pihak yang berkepentingan. Untuk itu sistem distribusi zakat berarti pengumpulan atau komponen baik fisik maupun nonfisik yang saling berhubungan satu sama lain dan bekerjasama secara harmonis untuk menyalurkan zakat yang terkumpul kepada pihak tertentu dalam meraih tujuan sosial ekonomi dari pemungutan zakat.

Sistem distribusi zakat mempunyai sasaran dan tujuan. Sasarannya adalah pihak-pihak yang diperbolehkan menerima zakat; sedangkan tujuannya adalah sesuatu yang dapat dicapai dari alokasi hasil zakat dalam kerangka sosial ekonomi, yaitu meningkatkan kesejahteraan masyarakat dalam bidang perekonomian sehingga dapat memperkecil kelompok masyarakat miskin, yang pada akhirnya akan meningkatkan kelompok muzakki.(Mursyidi, 2003)

Pola pendistribusian zakat saat ini juga mengalami inovasi, sebagaimana yang dicanangkan dalam buku Pedoman Zakat yang diterbitkan Ditjen Bimas Islam dan Urusan Haji Departemen Agama (2002: 244), bentuk inovasi distribusi dikategorikan dalam empat bentuk yaitu, Distribusi konsumtif tradisional, konsumtif kreatif, produktif tradisional, produktif kreatif.

\section{Tinjauan tentang Zakat}

Zakat adalah isim masdar dari kata zaka-yazku-zakah. Oleh karena kata dasar zakat adalah zaka yang berarti berkah, tumbuh, bersih, baik, dan bertambah. Dengan makna tersebut, orang yang telah mengeluarkan zakat diharapkan hati dan jiwanya akan menjadi bersih.(Fakhrudin, 2008)

\section{Metode}

Tujuan penelitian ini adalah untuk melihat bagaimana manajemen pendistribusian zakat yang dilakukan oleh BAZNAS Provinsi Kalimantan Selatan. Jenis penelitian adalah penelitian lapangan (field research) dimana penulis langsung ke lapangan untuk memperoleh data-data yang berkaitan dengan penelitian ini. Sumber data yang digunakan berasal dari data primer berupa wawancara dan observasi serta data sekunder berupa buku-buku, dokumentasi, media internet yang ada kaitannya dengan penelitian yang akan dilakukan. Yang menjadi responden adalah karyawan yang mempunyai tanggung jawab dibidang pendistribusian dan pendayagunaan zakat.

\section{Hasil Penelitian dan Pembahasan Manajemen Pendistribusian}

Penelitian ini mencoba menganalisis manajemen pendistribusian zakat di BAZNAS Provinsi Kalimantan Selatan mencakup aktivitas perencanaan, pengorganisasian, pelaksanaan/penggerakan, dan pengawasan terhadap pendistribusian zakat. 
a. Perencanaan

Perencanaan Pendistribusian zakat di BAZNAS Provinsi Kalimantan Selatan diberikan berdasarkan permohonan dari pihak eksternal baik individu maupun lembaga, melihat dari kondisi atau kebutuhan dari masyarakat itu tersendiri. Bidang Pendistribusian dan Pendayagunaan membuat RKAT (Rencana Kerja Anggaran Tahunan) atau Renstra (Rencana Strategis) BAZNAS Provinsi Kalimantan Selatan, terdiri dari program-program yang akan dilaksanakan. RKAT itu akan dibawa ke Rapat Pleno, dari keputusan rapat pleno itulah, maka RKAT itu akan dilaksanakan dalam 5 tahun kedepan.

Program-program yang dibuat oleh bidang pendistribusian dan pendayagunaan itu mengacu pada visi dari BAZNAS Provinsi Kalimantan Selatan "ampih miskin dengan sentuhan zakat" akan tercapai, dengan target mengentaskan kemiskinan sebanyak $1 \%$ dari keluarga miskin yang ada di Kalimantan Selatan.

Dalam merealisasikan visi tersebut, maka BAZNAS Provinsi Kalimantan Selatan merencanakan program-program pendsitribusian dan pendayagunaan, sebagai berikut:

TABEL 4.3 PROGRAM PENDISTRIBUSIAN ZIS DIKELOMPOKKAN DALAM BERDASARKAN BIDANG DAN ASNAFNYA

\begin{tabular}{|l|c|c|c|c|c|}
\hline \multirow{2}{*}{ Asnaf/ Bidang } & \multicolumn{3}{|c|}{ Sosial } & \multirow{2}{*}{ Ekonomi } & \multirow{2}{*}{ Dakwah } \\
\cline { 2 - 6 } & pendidikan & Kesehatan & Kemanusiaan & & \\
\hline Fakir & $\mathrm{V}$ & $\mathrm{V}$ & $\mathrm{V}$ & & $\mathrm{V}$ \\
\hline Miskin & $\mathrm{V}$ & $\mathrm{V}$ & $\mathrm{V}$ & $\mathrm{V}$ & $\mathrm{V}$ \\
\hline Muallaf & & & & & $\mathrm{V}$ \\
\hline Riqab & & & & $\mathrm{V}$ & \\
\hline Gharimin & $\mathrm{V}$ & $\mathrm{V}$ & $\mathrm{V}$ & $\mathrm{V}$ & $\mathrm{V}$ \\
\hline Sabilillah & $\mathrm{V}$ & $\mathrm{V}$ & $\mathrm{V}$ & & \\
\hline Ibnu Sabil & & & $\mathrm{V}$ & & \\
\hline
\end{tabular}

Berdasarkan tabel di atas dapat diketahui klasifikasi program pendistribusian zakat dikelompokkan berdasarkan bidang dan asnafnya, terdiri dari bidang Sosial, Ekonomi dan Dakwah. Untuk pembagiannya bidang sosial meliputi: program pendidikan (fakir, miskin, gharimin, sabilillah), program kesehatan (fakir, miskin, gharimin, sabilillah), program kemanusiaan (fakir, miskin, gharimin, sabilillah, dan ibnu sabil), Sedangkan bidang dakwah meliputi: program 
ekonomi (miskin, muallaf dan sabilillah), dan program dakwah (fakir, miskin, muallaf dan sabilillah).

Baznas Provinsi Kalsel dalam perencanaan setiap program yang dibuatnya menentukan pula indikator-indikator keberhasilan sebagai standar untuk mengukur keberhasilan program. Dalam hal ini, untuk pendistribusian secara global, Baznas Pusat juga mengadakan kaji dampak yaitu IZN (Indeks Zakat Nasional). Berdasarkan prosedur seharusnya DPR yang memberi anggaran untuk biaya operasional, akan tetapi itu belum ada.

\section{b. Organizing (Pengorganisasian)}

Apabila perencanaan telah dilaksanakan, maka selanjutnya adalah melakukan pengorganisasian. Dalam proses pengorganisasian pendistribusian dan pendayagunaan di BAZNAS Provinsi Kalimantan Selatan, memiliki struktural sebagai berikut:

TABEL 4.4 STRUKTURAL BIDANG PENDISTRIBUSIAN DAN PENDAYAGUNAAN

\begin{tabular}{|l|l|}
\hline Wakil Ketua II Bidang & Drs. Irhamsyah Safari \\
\hline Ketua Bidang & Saddam Nurhidayat, SH \\
\hline Staf Bidang & Rizqy Khairunnisa, SE \\
\hline Staf Amil Program & Noor Huda Fikri, SH \\
\hline
\end{tabular}

Berdasarkan tabel di atas, maka bidang penditribusian dan pendayagunaan terdiri dari Wakil Ketua II yang bertugas melaksanakan pengelolaan pendistribusian dan pendayagunaan zakat. Kabid dan Staf bidang bertugas membantu Direktur Amil dalam koordinasi pengelolaan pendistribusian dan pendayagunaan zakat. Staf amil program bertanggungjawab melaksanakan program-program yang sudah direncanakan. Dengan demikian, ia akan mudah untuk ditanya, diaudit atau dikoreksi ketika melakukan kesalahan, atau mendapat kompensasi ketika menunjukkan kinerja yang baik. Tanggung jawab disini bersifat individu, setiap pribadi karyawan bertanggung jawab terhadap tindakan dan kinerja yang dilakukan.(Ahmad Abrahim Abu Sinn, 1996)

Selain struktur di atas terdapat relawan yang membantu dalam pelaksanaan program yang akan dilaksanakan. Karena mereka masih kekurangan sumber daya manusia yang sesuai dengan bidang tersebut, khususnya yang bertugas dilapangan.

Untuk prosedur menjadi mustahik perorangan berupa; copy KTP, KK, SKTM, dan dokumen pendukung seperti keterangan dari sekolah, rumah sakit atau pihak terkait lainnya. Kemudian untuk mustahik lembaga berupa; copy Anggaran Dasar, perizinan dari Kementrian terkait, copy KTP Pengurus dan legalitas lain yang diperlukan. Dan itu semua harus diverifikasi terlebih dahulu dan dipertimbangkan berdasarkan had kifayah. Had Kifayah merupakan batas 
kecukupan atau standar dasar kebutuhan seseorang/keluarga ditambah dengan kecukupan tanggungan yang ada sebagai upaya untuk menetapkan kelayakan penerima zakat mustahik fakir miskin sesuai kondisi wilayah dan sosio-ekonomi setempat. Adanya Had Kifayah sangat membantu dalam menggambarkan kadar kecukupan kehidupan seseorang atau sebuah rumah tangga, apakah tergolong mustahik fakir miskin atau tidak, yang ditentukan berdasarkan pada sebuah kondisi dan wilayah tertentu. (Divisi Publikasi dan Jaringan Pusat Kajian Strategis BAZNAS, 2018)

Dalam proses pendistribusian zakat yang ada di BAZNAS Provinsi Kalimantan Selatan selalu ada koordinasi baik di lapangan maupun di kantor, yaitu dengan adanya whatsapp group akan mempermudah komunikasi satu sama lain.

Pengorganisasian BAZNAS Provinsi Kalimantan Selatan bermitra atau mengadakan MoU dengan BAZNAS kabupaten kota, universitas, BMT Amanah, balai pelatihan kerja, dan lain-lain. Mitra-mitra inilah yang akan membantu dalam pelaksanaan program di lapangan.

\section{c. Actuating (Pelaksanaan/Penggerakan)}

Pelaksanaan/penggerakan pendistribusian zakat di BAZNAS Provinsi Kalimantan Selatan dilaksanakan secara bertahap dan terstruktur. Pola pendistribusian zakat terdiri dari konsumtif dan produktif sebagai pelaksanaan dari program-program yang telah direncanakan pada RKTA, yaitu:

TABEL 4.5 PROGRAM PENDISTRIBUSIAN DAN PENDAYAGUNAAN BAZNAS PROVINSI KALIMANTAN SELATAN

\begin{tabular}{|c|c|c|c|}
\hline No & Program & Jenis Bantuan & Pola Pendistibusian Zakat \\
\hline 1 & Ekonomi & $\begin{array}{l}\text { 1. Bantuan biaya tambahan } \\
\text { modal usaha } \\
\text { 2. Pendampingan dan } \\
\text { pembinaan keluarga } \\
\text { mustahik } \\
\text { 3. Pelatihan wirausaha } \\
\text { 4. Pelatihan otomotif } \\
\text { 5. Pedagang } \\
\text { 6. Bengkel AC } \\
\text { 7. Sentra ternak sapi }\end{array}$ & $\begin{array}{l}\text { 1. Produktif kreatif } \\
\text { 2. Konsumtif Tradisional } \\
\text { 3. Produktif Tradisonal } \\
\text { 4. Produktif Tradisional } \\
\text { 5. Produktif Kreatif } \\
\text { 6. Produktif Tradisional } \\
\text { 7. Produktif Tradisional }\end{array}$ \\
\hline 2 & Kemanusiaan & $\begin{array}{llr}\text { 1. } & \text { Paket Ramadhan Bahagia } \\
\text { 2. Hidangan } & \text { berkah } \\
& \text { Ramadhan } & \\
\text { 3. } & \text { THR Yatim } \\
\text { 4. Pemulangan } & \text { orang } \\
& \text { terlantar } & \end{array}$ & $\begin{array}{l}\text { 1. Konsumtif Tradisional } \\
\text { 2. Konsumtif Tradisional } \\
\text { 3. Konsumtif Kreatif } \\
\text { 4. Konsumtif Tradisional } \\
\text { 5. Konsumtif Tradisional }\end{array}$ \\
\hline
\end{tabular}




\begin{tabular}{|c|c|c|c|}
\hline No & Program & Jenis Bantuan & Pola Pendistibusian Zakat \\
\hline & & $\begin{array}{l}\text { 5. Pelunasan hutang untuk } \\
\text { keluarga tidak mampu } \\
\text { 6. Bantuan bencana alam } \\
\text { 7. Biaya Hidup untuk } \\
\text { mustahik fakir }\end{array}$ & $\begin{array}{l}\text { 6. Konsumtif Tradisional } \\
\text { 7. Konsumtif Tradisional }\end{array}$ \\
\hline 3 & Kesehatan & $\begin{array}{l}\text { 1. Teras sehat } \\
\text { 2. Layanan Aktif BAZNAS } \\
\text { sehat } \\
\text { 3. Bantu biaya iuran BPJS } \\
\text { 4. Layanan kesehatan ibu } \\
\text { hamil } \\
\text { 5. Layanan kesehatan anak } \\
\text { berkebutuhan khusus }\end{array}$ & Konsumtif Kreatif \\
\hline 4 & Pendidikan & $\begin{array}{ll}\text { 1. } & \text { Beasiswa Pendidikan } \\
\text { 2. } & \text { Beasiswa WASAKA } \\
\text { BAZNAS } & \\
\text { 3. } & \text { Beasiswa BAZNAS } \\
\text { tingkat SD, SMP, SMA } \\
\text { dan Perguruan tinggi }\end{array}$ & Konsumtif Kreatif \\
\hline 5 & $\begin{array}{c}\text { Dakwah dan } \\
\text { Advokasi }\end{array}$ & $\begin{array}{l}\text { 1. Biaya } \\
\text { rehab/pembangunan } \\
\text { rumah ibadah } \\
\text { 2. Biaya } \\
\text { rehab/pembangunan dan } \\
\text { pengadaan sarana belajar } \\
\text { Islam } \\
\text { 3. Ramadhan tebar Al- } \\
\text { Our'an } \\
\text { 4. Biaya hidup Da'i } \\
\text { 5. Dukungan untuk para } \\
\text { muallaf }\end{array}$ & $\begin{array}{l}\text { 1. Konsumtif Kreatif } \\
\text { 2. Konsumtif Kreatif } \\
\text { 3. Kosumtif Kreatif } \\
\text { 4. Konsumtif Tradisional } \\
\text { 5. Konsumtif Kreatif }\end{array}$ \\
\hline
\end{tabular}

Berdasarkan tabel di atas menunjukan pola pendistribusian konsumtif dan produktif sebagai pelaksanaan dari program-program yang telah direncanakan pada Rencana Kerja Anggaran Tahunan (RKTA). BAZNAS Provinsi Kalimantan Sealatan lebih dominan melaksanakan pola pendistribusian yang bersifat konsumtif kreatif.

1) Distribusi bersifat "Konsumtif Tradisional" yaitu Pendampingan dan pembinaan keluarga mustahik, biaya hidup Da'i, paket ramadhan bahagia, hidangan berkah ramadhan, THR yatim, pelunasan hutang untuk keluarga tidak mampu, bantuan bencana alam, biaya hidup untuk mustahik fakir. 
2) Distribusi bersifat "Konsumtif Kreatif" yaitu pemulangan orang terlantar, teras sehat, layanan aktif BAZNAS sehat, bantu biaya iuran BPJS, layanan kesehatan ibu hamil, layanan kesehatan anak berkebutuhan khusus, Beasiswa Pendidikan, Beasiswa WASAKA BAZNAS, Beasiswa BAZNAS tingkat SD, SMP, SMA dan Perguruan tinggi, Biaya rehab/pembangunan rumah ibadah, biaya rehab/pembangunan dan pengadaan sarana belajar islam, ramadhan tebar Al-Qur'an

3) Distribusi bersifat "Produktif Tradisional" yaitu pelatihan wirausaha, pelatihan otomotif, pelatihan bengkel AC, sentra ternak sapi.

4) Distribusi bersifat "Produktif Kreatif" yaitu bantuan biaya tambahan modal usaha, pedagang.

Pelaksanaan pendistribusian zakat biasanya dilakukan dengan mengumpulkan mustahik dalam satu tempat, kemudian di sana diagendakan acara penyerahan pendistribusian. Kemudian dalam bentuk lain, amil datang langsung untuk mendistribusikan zakat ke mustahik yang terutama berada di daerah-daerah jauh dan terpencil. Untuk kegiatan seperti pelatihan, maka perlu diagendakan terlebih dahulu."

Pelaksanaan pendistribusian zakat di BAZNAS Provinsi Kalimantan Selatan belum merata, dikarenakan adanya asnaf yang diutamakan terlebih dahulu yaitu asnaf fakir dan miskin, kemudian dengan keterbatasan sarana dan prasarana, sumber daya manusia, dan ada beberapa kabupaten yang partisipasi pelaporannya tidak menunjukkan peningkatan sehingga dilakukan pembinaan. Pada beberapa kabupaten yang melaksanakan pendistribusian serta pelaporan yang jelas, tentu akan membantu Baznas Provinsi dalam hal pendistribusian, walaupun pendistribusian ini belum merata. Pendistribusian di daerah akan disupport oleh Baznas Provinsi apabila program yang dijalankan sesuai dengan program mereka. 


\section{GAMBAR 4.1 RENCANA \& REALISASI PENYALURAN BERDASARKAN ASNAF PERIODE 1 JANUARI S/D 31 DESEMBER TAHUN 2018}

\begin{tabular}{|c|c|c|c|c|}
\hline \multicolumn{5}{|c|}{$\begin{array}{l}\text { BAZNAS PROVINSI KALIMANTAN SELATAN } \\
\text { RENCANA \& REALISASI PENYALURAN BERDASARKAN ASNAF } \\
\text { Periode } 1 \text { Januari s/d } 31 \text { Desember Tahun } 2018\end{array}$} \\
\hline No & Keterangan: & Rencana (Rp) & Realisas! (Rp) & Capaian $(\%)$ \\
\hline 1 & 2 & 3.00 & 4.00 & $5=4 / 3$ \\
\hline 1 & Penyaluran Dana Zakat & $2,565,000,000.00$ & $2,247,051,759.00$ & $87.60 \%$ \\
\hline 1.1 & Penyaluran dana zakat untuk Fakir & 300.000 .000 .00 & & $0.00 \%$ \\
\hline 12 & Penyaluran dana zakat untuk Miskin & $1.280,000,000.00$ & 1.890 .004 .896$. on & $147.66 \%$ \\
\hline 1.3 & Penyaluran dana (alokasi) zakat unituk Amil & 277.500 .000 .00 & $25 z: 868.251 .00$ & $91.12 \%$ \\
\hline 1.4 & Penyaluran dana zakat untuk Muallaf & 50.000 .000 .00 & 5.000 .000 .00 & $1000 \%$ \\
\hline 1.5 & Penyaluran dana zakat untuk Riqob & & & $0.00 \%$ \\
\hline 1.6 & Penyaluran dana zakat untuk Gtıarimin & 262.500 .000 .00 & 5.365 .000 .00 & $204 \%$ \\
\hline 17 & Penyaluran dana zakat untuk Fisabilillah & $385,000.000 .00$ & $84,703.612 .00$ & $2200 \%$ \\
\hline 1.8 & Penyaluran dana zakat untuk Ibnu Sabil & 10.000 .000 .00 & 9.110 .00000 & $91.10 \%$ \\
\hline 2 & Penyaluran Dana Infak/Sedekah & $1,372,500,000.00$ & $1,903,273,127.80$ & $138.67 \%$ \\
\hline 2.1 & Penyaluran dana infak/sedekah untuk Fakir & 250.000 .000 .00 & $21,000,00000$ & $8.40 \%$ \\
\hline 2.2 & Penyaluran dana infak/sedekah untuk Miskin & 705.000 .000 .00 & 825.131 .166 .00 & $11704 \%$ \\
\hline 23 & Penyaluran dana (alokasi) infak untuk Amil & $212,500,000.00$ & $456,835,961,80$ & $214.98 \%$ \\
\hline 24 & Penyaluran dana infak'sedekah untuk Muallaf & & & $0.00 \%$ \\
\hline 2.5 & Penyaluran dana infak/sedekah untuk Riqob . & & & $0.00 \%$ \\
\hline 2.6 & Penyaluran dana infak/sedekah untuk Gharimin & 70.000 .000 .00 & & $0.00 \%$ \\
\hline 2.7 & Penyaluran dana infak/sedekah untuk Fisabilillah & 125.000 .00000 & 600.306 .000 .00 & $48024 \%$ \\
\hline 28 & Penyaluran dana infak/sedekah untuk Ibnu Sabil & 10.000 .000 .00 & & $0.00 \%$ \\
\hline 3 & Penyaluran Dana Corporate Social Responsiblity & $90,000,000.00$ & & $000 \%$ \\
\hline 3.1 & Penyaluran dana CSR & 90.000 .00000 & & $0.00 \%$ \\
\hline 3.2 & Penyaluran dana CSR untuk Amil & & & $0.00 \%$ \\
\hline 4 & $\begin{array}{l}\text { Penyaluran Dana Sosial Keagamaan Lainnya (DSKL) (hibah, } \\
\text { nazar, pusaka yang tidak memiliki ahli waris, kurban, kafarat, } \\
\text { fidiyah, denda atau sitaan pengadilan agama, dsb) }\end{array}$ & $160,000,000.00$ & $17,140,000.00$ & $10.71 \%$ \\
\hline 4.1 & Penyaluran dana DSKL & 160.000 .000 .00 & & $0.00 \%$ \\
\hline 4.2 & Penyaluran daria DSKL untuk Amil & & & $0.00 \%$ \\
\hline & TOTAL PENYALURAN & $4,187,500,000.00$ & $4,167,464,886.80$ & $99.52 \%$ \\
\hline
\end{tabular}

Berdasarkan gambar diatas BAZNAS Provinsi Kalimantan Selatan menyalurkan sesuai dengan objek pendistribusian atau mustahik yaitu kepada 8 Asnaf, kecuali Asnaf Riqob. Adapun capaian realisasi penyaluran berdasarkan asnaf selama enam bulan berjalan dengan rencana penyaluran sebesar Rp. 4.187.500.000,-, dan penyaluran terealisasi Rp. 4.167.464.887 atau sebesar 99,52\%. Hal tersebut memberikan gambaran BAZNAS Provinsi Kalimantan Selatan memiliki komitmen tinggi dalam melakukan Pendistribusian dan Pendayagunaan demi memberikan manfaat yang besar dalam pengentasan kemiskinan yang ada. 


\section{GAMBAR 4.2 RENCANA DAN REALISASI PENYALURAN BERDASARKAN PROGRAM}

PERIODE 1 JANUARI S/D 31 DESEMBER TAHUN 2018

\begin{tabular}{|c|c|c|c|c|}
\hline & $\begin{array}{l}\text { BAZNAS PROVINSI KAL } \\
\text { RENCANA \& REALISASI PENYALUR } \\
\text { Periode } 1 \text { Januari s/d } 31\end{array}$ & $\begin{array}{l}\text { NTAN SEL } \\
\text { RDASARKAN PR } \\
\text { nber Tahun } 20\end{array}$ & $\begin{array}{l}\text { ATAN } \\
\text { OGRAM* } \\
8\end{array}$ & \\
\hline No & Keterangan & Renrana (Rp) & Realisasi (Rp) & Capaian $(\%)$ \\
\hline$\frac{1}{1}$ & Penyaluran Dana Zakat & 300 & 4.00 & $5=4 / 3$ \\
\hline & Penyaluran Dana Zakat & $3,297,500,000.00$ & $2,094,019,896.00$ & $91.14 \%$ \\
\hline 1.1 & Penyaluran dana zakat untuk Pendidikan & $602.500,000.00$ & $888.154,000.00$ & $147.41 \%$ \\
\hline 12 & Penyaluran dana zakat untuk Kesehatan & $260,000,000.00$ & $518,760,000,00$ & $199.52 \%$ \\
\hline 1.3 & Penyaluran daria zakat untuk Kemanusiaan & 240.000 .000 .00 & $314,092,696.00$ & $151.25 \%$ \\
\hline 1.4 & Penyalurau dana zakat untuk Ėkonomi & $1.007 .500,000.00$ & $330,813,200.00$ & $32.84 \%$ \\
\hline 1.5 & Penyaluran dana zakat untuk Dakwah-Advokasi & $187,500,000.00$ & $41.300,000.00$ & $22.03 \%$ \\
\hline 2 & Penyaluran Dana Infak/Sedekah & $1,150,000,000.00$ & $1,343,997,166.00$ & $11686.93 \%$ \\
\hline 2.1 & Penyaluran dana infak/sedekah untuk Pendidikan & $320,000,000.00$ & $90,928,000.00$ & $28.42 \%$ \\
\hline 2.2 & Penyaluran dana infak/sedekah untuk Kesehatan & $80,000.000 .00$ & $57,330,000.00$ & $71.66 \%$ \\
\hline 2.3 & Penyaluran dana infak/sedekah untuk Kemanusiaan & $197,000,000.00$ & $590,883,166.00$ & $299.94 \%$ \\
\hline 2.4 & Penyaluran dana infak/sedekah untuk Ekonomi & $438.000,000.00$ & $4,550,000.00$ & $1.04 \%$ \\
\hline 2.5 & Penyaluran dana infak/sedekah untuk Dakwah & $115,000,000.00$ & $600,306,000,00$ & $522.01 \%$ \\
\hline 3 & Penyaluran Dana Corporate Social Responsiblity & $90,000,000.00$ & & $0.00 \%$ \\
\hline 3.1 & Penyaluran dana CSR untuk Pendidikan & & & $0.00 \%$ \\
\hline 3.2 & Penyaluran dana CSR untuk Kesehatan & $90,000,000.00$ & & $0.00 \%$ \\
\hline 3.3 & Penyalitran dana CSR untuk Kemanusiaan . & & & $0.00 \%$ \\
\hline 3.4 & Penyaluran dana CSR untuk Ekonomi & & & $0.00 \%$ \\
\hline 3.5 & Penyaluran dana CSR untuk Dakwah-Advokasi & & & $0.00 \%$ \\
\hline 4 & $\begin{array}{l}\text { Penyaluran Dana Sosial Keagamaan Lainnya (DSKL) } \\
\text { (hibah, nazar,pusaka yang tidak memiliki ahli } \\
\text { waris,kurban,kafarat,fidiyah,denda atau sitaan pengadilan } \\
\text { aaama, dsb) }\end{array}$ & $160,000,000.00$ & $17,140,000.00$ & $10.71 \%$ \\
\hline 4.1 & Penyaluran DSKL untuk Pendidikan & & & $0.00 \%$ \\
\hline 4.2 & Penyaluran DSKL. untuk Kesehatan & & & $0.00 \%$ \\
\hline 4.3 & Penyaluran DSKL untuk Kemanusiaan & $160,000,000.00$ & $17,140,000.00$ & $10.71 \%$ \\
\hline 44 & Penyaluran DSKL untuk Ekonomi & & 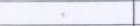 & $0.00 \%$ \\
\hline 4.5 & Penyaluran DSKL untuk Dakwah & & & $0.00 \%$ \\
\hline & TOTAL PENYALURAN & $3,697,500,000.00$ & $3,455,157,062.00$ & $93.45 \%$ \\
\hline
\end{tabular}

Dari gambar diatas maka dapat diketahui didalam Rencana Kerja Anggaran Tahunan (RKAT) tahun 2018 BAZNAS provinsi kalimantan selatan dalam perencanaan penyaluran terbagi dalam beberapa program seperti bidang pendidikan, kesehatan, kemanusiaan, ekonomi dan dakwah advokasi. Adapun penyaluran yang telah terealisasi diseluruh program tersebut dengan variasi nilai yang berbeda-beda. Adapun pecapaian penyaluran sebesar 93,46\% dari tagert yang telah ditetapkan.(Laporan keuangan zakat BAZNAS, 2018)

d. Controlling (Pengawasan)

Proses pengawasan pendistribusian zakat di BAZNAS Provinsi Kalimantan Selatan melalui pendampingan dari segi pendapatan, segi ekonomi, segi loyalitas yang bisa diberikan terhadap BAZNAS.

Proses pengawasan kepada mustahik dilakukan dengan mengadakan monitoring dan evaluation (monev) sebulan sekali. Untuk program zakat produktif BAZNAS Provinsi Kalimantan Selatan bekerja sama dengan BMT Amanah, sebagai lembaga keuangan yang ditunjuk untuk mengelola tabungan hasil usaha mustahik setiap bulannya. Untuk program 
konsumtif yang seharusnya dari pusat adanya pendampingan. Akan tetapi dengan keterbatasan SDM (Sumber Daya Manusia) dan tidak adanya anggaran untuk pendampingan, maka tidak dapat didampingi secara terus menerus.

Dalam proses pengawasan bidang pendistribusian dan pendayagunaan di BAZNAS Provinsi Kalimantan Selatan, dilakukan oleh satuan audit internal. Satuan audit internal secara langsung mengawasi kinerja bidang penditribusian dan pendayagunaan agar kinerja bidang pendistribusian dan pendayagunaan sesuai dengan syariah dan undangundang. Hasil dari Pengawasan itu kemudian dilaporkan kepada Kementrian Agama. Bahkan menurut undang-undang Dewan Perwakilan Rakyat (DPR) juga berhak mendapatkan laporan dari BAZNAS, akan tetapi hubungan itu belum ada. DPR terkesan acuh tentang adanya undang-undang zakat tersebut, jadi dalam pengawasan BAZNAS Provinsi Kalimantan selatan seharusnya ada dari ekstenal. Sementara ini Badan Amil Zakat di bawah naungan Pemerintah Provinsi.

Faktor-faktor Pendukung dan Penghambat Pendistribusian Zakat di BAZNAS Provinsi Kalimantan Selatan

a. Faktor pendukung

1) Internal

a) Sarana prasarana kantor

Sarana dan prasarana kantor akan memudahkan bagi amil dalam pelaksanaan pendistribusian zakat ke berbagai daerah yang ada di Kalimantan Selatan. Baik dari segi transportasi dan logistik.

b) Strategi Pendistribusian

Dalam pelaksanaan penditribusian zakat, strategilah yang sangat penting dalam hal merencanakan, melaksanakan kemudian mengevaluasinya. Tujuan dari strategi adalah untuk mencapai tujuan, yaitu dengan taktik atau cara tersendiri yang telah di tetapkan di awal perencanaan.

2) Eksternal

a) Kajian-kajian atau penelitian dari kampus

kajian-kajian dari kampus ini akan membantu lembaga zakat dalam membenahi segala aspek yang berhubungan dengan zakat.

b) Mitra-mitra

Mitra adalah salah satu faktor pendukung yang sangat kompleks dalam pelaksanaan suatu program, yang mana mitra inilah yang akan membantu dalam proses pelaksanaan dan pengawasan.

b. Faktor Penghambat

1) Internal

a) Sumber Daya Manusia (SDM) 
Faktor penghambat yang dialami BAZNAS Provinsi Kalimantan Selatan yaitu terbatasnya tenaga SDM untuk proses pendistribusian zakat. Dalam menangani proses pendistribusian zakat tentunya dilakukan survey ke lapangan. BAZNAS provinsi Kalimantan Selatan belum memililki orang yang professional dalam bidangnya, sehingga mencari relawan untuk membantu proses tersebut.

b) Kebijakan/kendala di lapangan

Kebijakan/kendala di lapangan ini biasanya hal yang tak terduga yang terjadi pada saat dilapangan, yang mana membuat pimpinan atau amil pelaksana membuat kebijakan diluar dari perencanaan sebelumnya.

2) Eksternal

a) Kurang dukungan dari pemerintah

BAZNAS Provinsi Kalimantan Selatan belum ada dukungan dari pemerintah dalam hal anggaran biaya operasional. Apabila sumber Anggaran Pendapatan dan Belanja Daerah (APBD) ada, maka itu sangat memudahkan untuk pendistribusian.

b) Kesalahan administrasi permohonan mustahik

Sebagian dari para calon mustahik mengajukan permohonan bantuan ada yang salah persepsi. Ada yang beranggapan bahwa BAZNAS Provinsi Kalimantan Selatan memberikan pinjaman modal usaha, padahal yang sebenarnya BAZNAS Provinsi Kalimantan Selatan memberikan bantuan modal usaha. Kemudian persyaratan calon mustahik kurang lengkap, itu yang menghambat proses pendistribusian zakat.

c) Kesulitan dalam pengawasan terhadap mustahik Untuk proses pengawasan terhadap mustahik mengalami kesulitan karena jumlah mustahik yang banyak, sehingga menyulitkan dalam proses Monitoring dan evaluation (monev).

d) Akses jalan proses pendistribusian

Proses pendistribusian ke mustahik sebagian akses jalan sangat sulit dan jauh. Dengan demikian akan memperlambat waktu pendistribusian sampai ke tangan mustahik.

\section{Simpulan}

Berdasarkan hasil penelitian dapat disimpulkan bahwa Manajemen yang diterapkan dalam proses penditribusian zakat di BAZNAS Provinsi Kalimantan Selatan sudah melakukan tahapan-tahapan sesuai teori manajemen, yaitu perencanaan, pengorganisasian, pelaksanaan/penggerakan, dan pengawasan.

Faktor-faktor Pendukung dan Penghambat Pendistribusian Zakat di BAZNAS Provinsi Kalimantan Selatan: 
a. Faktor-faktor pendukung, yaitu Sarana dan prasarana kantor, strategi pendistribusian yang baik, kajian-kajian atau penelitian dari kampus, dan dukungan mitra-mitra BAZNAS Provinsi Kalimantan Selatan.

Faktor-faktor penghambat, yaitu Sumber Daya Manusia (SDM), kebijakan, kurang dukungan dari pemerintah, kesalahan penulisan dalam surat permohonan mustahik, penyebaran mustahik yang cukup luas dan sulit dijangkau dan kesulitan dalam proses pengawasan terhadap mustahik.

\section{Referensi}

Ahmad, Tanzeh. 2009. Pengantar Metode Penelitian. Yogyakarta: TERAS

Aliy, As'ad. 1979. Fathul Mu'in jilid 2. Yogyakarta: Menara Kudus

Andi, Prastowo. 2014. Memahami Metode-metode Penulisan. Yogyakarta: Ruzz Media

Brosur BAZNAS Provinsi Kalimantan selatan

Departemen Agama RI. 2007. Manajemen Pengelolaan Zakat. Jakarta: Direktorat Pemberdayaan Zakat Ditjen Bimas Islam

Divisi Publikasi dan Jaringan Pusat Kajian Strategis BAZNAS. 2018. Had Kifayah. Jakarta: Pusat Kajian Strategis Badan Amil Zakat Nasional (BAZNAS)

Eri, Sudewo. 2004. Manajemen Zakat, Jakarta: Institut Manajemen Zakat

Fakhruddin. 2008. Fiqh \& Manajemen Zakat di Indonesia. Malang: UIN-Malang Press

Hasbi, Ash-Shiddieqy. 1953. Pedoman Zakat. Jakarta: PT Bulan Bintang

Ilyas, Supena dan Darmuin. 2009. Manajemen Zakat. Semarang: Walisongo Press

Kementerian Agama Republik Indonesia Direktorat jendral Bimbingan Masyarakat Islam Direktorat Pemberdayaan Zakat. 2012. Profil LPZ. Jakarta: Kemenag

Kementerian Agama RI. 2012. Al-Qu'an dan Terjemahnya. Jakarta: PT Sinergi Pustaka Indonesia

Kementrian Agama RI. 2011. Petunjuk Pelaksanaan Pengumpulan Zakat. Jakarta: Direktorat Pemberdayaan Zakat

Lasa, H.S. 2008. Manajemen Perpustakaan. Yogyakarta: Gama Media

Laporan Kinerja, Laporan Keuangan dan Laporan Pengelolaan Zakat per 31 Desember 2018 BAZNAS Provinsi Kalimantan Selatan

M, Munir. 2009. Manajemen Dakwah, Jakarta: Kencana

Malayu S.P, Hasibuan. 1995. Manajemen Sumber Daya Manusia: Dasar dan Kunci Keberhasilan. Jakarta: Toko Gunung Agung

Mufraini, Arif. 2006. Akutansi dan Manajemen Zakat. Jakarta: Kencana

Muhammad, Hadi. 2010. Problematika Zakat Profesi dan Solusinya. Yogyakarta: Pustaka pelajar

Mu'is, Fahrur. 2011. Zakat A-Z Panduan Mudah, Lengkap, dan Praktis tentang Zakat. Solo: Tinta Medina

Organizational Body. 2018. Fikih Zakat Kontekstual Indonesia. Jakarta: Badan Amil Zakat Nasional

Poerwadaminta W.H.S. 1999. Kamus Umum Bahasa Indonesia, Cet. 7. Jakarta: Balai Pustaka PUSKAS BAZNAS. 2016. Outlook Zakat Indonesia 2017. Cet. 2. Jakarta: PUSKAS BAZNAS

Saifudin, Zuhri. 2012. Zakat antara cita dan fakta, Semarang: Fakultas Tarbiyah IAIN Walisongo

Sinn Ahmad Abrahim, Abu. 1996. Manajemen Syariah, Sebuah Historis dan Kontemporer. Jakarta: Rajagrafindo Persada.

Sudirman. 2007. Zakat dalam Pusaran Arus Modernitas. Malang: UIN-Malang Press

Sugiyono. 2008. Penelitian Kualitatif dan Kuantitatif. Bandung: Alfabeta

Sukarno. 2011. Dasar-dasar Manajemen. Bandung: CV. Maju Mundur

Tim Penyusun. 2015. Pedoman Penulisan Skripsi IAIN Antasari. Banajrmasin: Fakultas Dakwah dan Komunikasi IAIN Antasari Banjarmasin. 
Tim Penyusun. 2017. Kumpulan Khutbah Zakat. Jakarta: Badan Amil Zakat Nasional Ursyidi. 2003. Akutansi Zakat Kontemporer. Bandung: PT Remaja Rosdakarya.

Usman dan Purnomo Setia Akbar. 2001. Metodologi Penelitian Sosial. Cet. 4. Jakarta: Bumi Asara.

Yasin Ibrahir, Al-Syaikh. 2008. Kitab Zakat Hukum, Tata Cara dan Sejarah. Bandung: Penerbit Marja

Internet:

Kamus Besar Bahasa Indonesia (KBBI). Pengertian Pendistribusiaan.

https://kbbi.web.id/distribusi diakses pada Hari Rabu tanggal 3 januari 2018 Pukul 19.25 Wita 